\title{
Climate Change, Sustainable Development, and Human Rights
}

\begin{abstract}
Alan Boyle
Contents

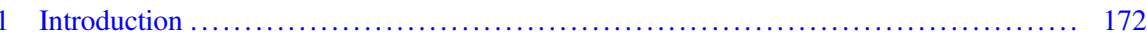

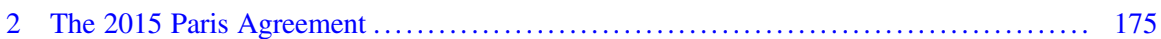

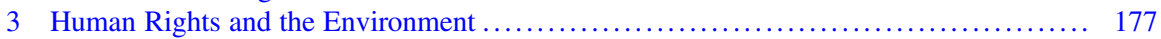

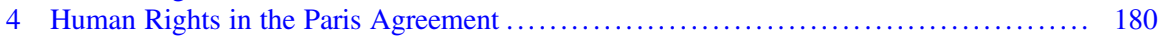

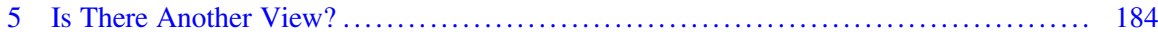

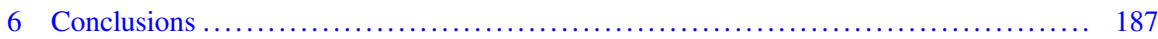

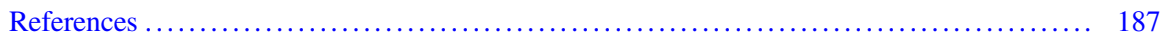

\begin{abstract}
Climate change is a global problem. Addressing it is one of the UN's Sustainable Development Goals, which the 2015 Paris Agreement is intended to implement. It will also affect the enjoyment of human rights in many ways, but its causes, its effects, and those responsible, are too numerous and too widely spread to respond usefully to individual human rights claims or to analysis by reference to particular human rights. The 2015 Paris Agreement is relevant to human rights law, not for what it says about human rights - which is next to nothing — but for what it says about the need to address the risk of climate change taking global temperatures above $1.5^{\circ} \mathrm{C}$. The UN special rapporteur is right in principle to argue that human rights law as a whole requires states to comply with expectations set out in Articles 2, 3 and 4 of the Agreement. UN human rights bodies need to act accordingly and hold states to account for what they have agreed in Paris.
\end{abstract}

A revised and updated version of this chapter was published in 67 ICLQ (2018) pp. 759-777.

\footnotetext{
A. Boyle (ه)

University of Edinburgh, Edinburgh Law School, Edinburgh, UK

e-mail: Alan.Boyle@ed.ac.uk

(C) The Author(s) 2020

M. Kaltenborn et al. (eds.), Sustainable Development Goals and Human Rights, Interdisciplinary Studies in Human Rights 5,

https://doi.org/10.1007/978-3-030-30469-0_10
} 


\section{Introduction}

Climate change is a threat to life on Earth as we know it. The Intergovernmental Panel on Climate Change ("IPCC") concludes that evidence of changes in the climate system is now unequivocal, with the atmosphere and oceans warming, glaciers and polar ice melting, sea levels rising, and greenhouse gas ("GHGs") concentrations increasing. ${ }^{1}$ Atmospheric greenhouse gas concentrations now stand at levels unprecedented in the past 800,000 years. The oceans have mitigated climate change, with $30 \%$ of the anthropogenic $\mathrm{CO}_{2}$ emissions being absorbed, making the oceans warmer and more acidic. ${ }^{2}$ The Kyoto Protocol, adopted in 1997 as a first step towards stabilising the climate, has been ineffective in reducing the increased concentration of atmospheric GHGs. On present trends, even if the 2015 Paris Agreement is fully implemented by all parties, it may be difficult to keep the increase in global temperatures below $2{ }^{\circ} \mathrm{C}$, let alone achieve the target of $1.5^{\circ} \mathrm{C}$. ${ }^{3}$

Unless we succeed in reducing and restraining the increase in global average temperatures the consequences for humanity will be increasingly serious, if not catastrophic. Already, the effects of climate change and the warming of the atmosphere and the oceans are starting to impact on water supplies, agriculture, forests, small islands, low-lying coastal areas, and the marine environment. They are causing or exacerbating desertification, extreme weather, flooding, loss of biodiversity and changes in the distribution and abundance of fish stocks. Various human rights are potentially affected: life, health, private life, property, the right to water, and the right to food and an adequate standard of living. Indigenous peoples, inhabitants of low lying islands and coastal areas, nomadic peoples, subsistence farmers and fishermen, may all be particularly vulnerable to the effects of climate change. So will the polar bear, the penguin and other wildlife species. But everyone will be vulnerable to climate change if attempts to control and mitigate its causes and effects do not succeed. This is a vision of unsustainable development over the long term. Thus the fundamental challenge posed by climate change is not so much to human rights here and now, but to future generations and humanity itself.

More than 30 years since it was first articulated by the Brundtland Report the concept of sustainable development remains almost infinitely malleable. ${ }^{4}$ However defined, it is inherently complex and its implementation obliges governments to think in somewhat different terms from those to which they have been accustomed. Social, political and economic choices abound: what weight should be given to natural resource exploitation over nature protection, to industrial development over

\footnotetext{
${ }^{1}$ See generally, Intergovernmental Panel on Climate Change (2013). Hereafter "IPCC 2013".

${ }^{2}$ IPCC 2013, paras. 2.2, 3.3, 5.2, 6.2-3.

${ }^{3}$ IPCC, Climate Change 2007: Synthesis Report (Bangkok, 2007); UN Environment Programme ["UNEP"], The Emissions Gap Report: Are the Copenhagen Accord pledges sufficient to limit global warming to $2^{\circ} \mathrm{C}$ or $1.5^{\circ} \mathrm{C}$ ? A preliminary assessment (Nairobi, 2010).

${ }^{4}$ See generally Redclift (1987); Jacobs (1991); Reid (1995); Moffatt (1995), esp. Ch 3; Goldin and Winters (1995); Dresner (2008); Neumayer (2013); Helm (2016).
} 
air and water quality, to land-use development over conservation of forests and wetlands, to energy consumption over the risks of climate change? The Sustainable Development Goals adopted by the UN recognise that it is for each state to make these choices. ${ }^{5}$ That may result in wide diversities of policy and interpretation, as different governments and international organisations pursue their own priorities and make their own value judgments, moderated only to some extent by international agreements on such matters as climate change and conservation of biological diversity.

Although "sustainable development" is used throughout the 1992 Rio Declaration on Environment and Development, and in Agenda 21, it was not until the 2002 World Summit on Sustainable Development that anything approaching a UN definition of the concept could be attempted. Three "interdependent and mutually reinforcing pillars of sustainable development" were identified in the Johannesburg Declaration-economic development, social development and environmental protection. ${ }^{6}$ In 2015 the UN went further and adopted an ambitious set of "Sustainable Development Goals" ("SDGs"). ${ }^{7}$ Like Agenda 21 in 1992, the Agenda for Sustainable Development affirms the need for a "global partnership for sustainable development", and the SDGs are intended to promote implementation of the concept. This vision of sustainable development mainly focuses on economic and social development; reduction of poverty and hunger are the pre-eminent objectives, but the SDGs cover almost every aspect of international policy, including well-being for all ages, gender equality, safer cities, better sanitation, sustainable consumption, access to justice, and so on.

While the preamble to the Agenda for Sustainable Development fully recognises the seriousness of the environmental challenge-including threats to the climate, biodiversity, water resources, and the marine environment-only three of the seventeen sustainable development goals are of particular relevance to the environment. The first commits states to take "urgent action" to deal with climate change and its impacts. ${ }^{8}$ At least in form they have now done so by adopting the 2015 Paris Agreement. ${ }^{9}$ The second addresses conservation and sustainable use of the oceans and marine resources. ${ }^{10}$ The third aims to conserve and sustainably manage terrestrial ecosystems such as forests and wetlands, combat desertification, and halt loss of biodiversity. ${ }^{11}$ All three are of course inter-linked. None of this adds anything new to international environmental policy or law, but it does serve to reaffirm existing

\footnotetext{
${ }^{5}$ See below.

${ }^{6} \mathrm{UN}$, Report of the World Summit on Sustainable Development [“WSSD”], UN Doc. A/CONF.199/ 20 (2002) Resolution 1, para. 5.

7“"Transforming Our World: the 2030 Agenda for Sustainable Development," UNGA Resolution 70/1 (2015).

${ }^{8}$ SDG 13.

${ }^{9}$ See below.

${ }^{10} \mathrm{SDG} 14$.

${ }^{11}$ SDG 15 .
} 
commitments within the context of a process whose outcomes the UN will review in due course. ${ }^{12}$

The SDGs have given the concept of sustainable development more concrete content, but they may also have under-estimated the seriousness of the environmental problems the world continues to generate on a global scale. This is the point made cogently by Helm, who observes that "It is not hard to make the case that the process of destruction [of natural capital] has gone too far, and that renewable natural capital as a whole is already well below the optimal level...The state of core ecosystem services, from climate to fresh water and soils, is already a serious cause for concern." 13

The key argument in this critique of existing conceptions of sustainability is that natural capital is not infinitely substitutable by man-made capital, and that some natural capital must be preserved in order to meet the needs of future generations and prevent ultimate catastrophe. ${ }^{14}$ Helm believes that international policy has been overly-focused on present generations, and that we need a stronger focus on the inheritance of future generations. ${ }^{15}$ Climate change and its consequences for global biodiversity, the oceans, and water supplies illustrate his point: put simply this and other long term environmental problems have not been given nearly enough weight in the balance of environment and development. To address this omission Helm formulates an "aggregate natural capital rule" designed to ensure that future generations inherit a comparable stock of natural capital even if it is not the same stock. ${ }^{16}$ He concludes that "no net loss would transform the environmental outlook."17

The "green economy" paradigm promoted by UN Environmental Programme ("UNEP") and the Organisation for Economic Cooperation and Development ("OECD") at the 2012 UN Conference on Sustainable Development ("UNCSD") was based on the same conclusion: it was intended to foster economic growth and development while ensuring that natural assets continue to provide the resources and environmental services on which human well-being now and in the future depends. ${ }^{18}$ As the 2012 negotiations got underway, however, it soon became evident that the "green economy" would not turn into a new consensus, but would reopen unresolved questions concerning the very notion of sustainable development. ${ }^{19}$ While some developed countries proposed the adoption of indicators to measure progress toward the green economy and the establishment of a capacity development scheme,

\footnotetext{
${ }^{12}$ UN General Assembly [“UNGA”] Resolution 70/1 (2015) paras. 72-91.

${ }^{13}$ Helm (2016), p. 63.

${ }^{14}$ Ibid, 54-62.

${ }^{15}$ Ibid, pp. 8, 40.

${ }^{16}$ Ibid, pp. 8, 40 .

${ }^{17}$ Ibid, p. 8 .

${ }^{18}$ UNEP, Global Green New Deal (Nairobi, 2009) and UNEP, Towards a Green Economy: Pathways to Sustainable Development and Poverty Eradication (Nairobi, 2011); OECD, Towards Green Growth (Paris, 2011); and World Bank, Inclusive Green Growth (Washington, 2012).

${ }^{19}$ Morgera and Savaresi (2012).
} 
developing countries largely resisted these suggestions, arguing that the green economy should not turn into a "normative straightjacket." 20 The guidance on the green economy eventually included in the conference outcome document ("The Future We Want") thus represents only a minimalist common denominator between these largely opposing views. ${ }^{21}$ It affirms that the green economy is but "one" of the tools available to achieve sustainable development, and should not be regarded as a "rigid set of rules." 22 All countries are encouraged to consider its implementation in a manner that "endeavours to drive sustained, inclusive and equitable economic growth and job creation." 23 Once again, the emphasis here is not on long-term sustainability of natural capital but on short term economic growth. This is the contested policy background against which we can now view the most recent agreement on climate change, the 2015 Paris Agreement.

\section{The 2015 Paris Agreement}

The Paris Agreement ${ }^{24}$ sets out a new agenda for implementing the UN Framework Convention on Climate Change ("UNFCCC") and the UN sustainable development goals post-Kyoto. ${ }^{25}$ Firstly it seeks to hold global temperature increases to "well below" $2{ }^{\circ} \mathrm{C}$ and if possible below $1.5^{\circ} .{ }^{26}$ It achieves this objective principally by committing all states parties to "prepare, communicate and maintain successive nationally determined contributions" to reducing GHG emissions. ${ }^{27}$ Secondly it seeks to enhance adaptation and climate resilience by promoting low carbon emissions development. ${ }^{28}$ It achieves this objective mainly through provision for cooperation and capacity building and by reiterating the UNFCCC"s provisions on

\footnotetext{
${ }^{20}$ Earth Negotiations Bulletin, Summary of the First PREPCOM for the UN Conference on Sustainable Development: 17-19 May 2010, at p. 5.

${ }^{21}$ UNCSD, The Future We Want, UN Doc A/CONF.216/L.1 (2012). For analysis, see Morgera and Savaresi (2012).

${ }^{22}$ The Future We Want, para. 56.

${ }^{23}$ Ibid, para. 62 .

${ }^{24}$ This is its full title. The Paris Agreement is in form, albeit not by name, a protocol to the 1992 UN Framework Convention on Climate Change ("UNFCCC"), with which it shares the same institutional features. It was adopted by decision of the parties to the UNFCCC and only parties to the UNFCCC may become parties to the Paris Agreement. It entered into force on 21 November 2016. See generally Bodansky (2016a).

${ }^{25}$ The commitments of developed state parties to reduce GHG emissions under the 1997 Kyoto Protocol expired in 2012 without having achieved any reduction in GHG emissions against the 1990 baseline.

${ }^{26}$ Article 2 .

${ }^{27}$ Articles 3 and 4 . See also Article 5 on conservation of carbon sinks (i.e. forests).

${ }^{28}$ Articles 2 and 7.
} 
financing. ${ }^{29}$ There is thus an implicit assumption in the Paris Agreement that sustainable development requires low carbon development and a cap on global temperature increases.

The Paris Agreement retains the controversial concept of common but differentiated responsibility on which the UN climate regime has until now been based,$^{30}$ but in a very different form. Unlike the Kyoto Protocol, all parties to Paris-not just the developed States parties - are expected to "prepare" some level of contribution to ensuring that GHG emissions peak as soon as possible and thereafter reduce rapidly so as to stabilise in the second half of the century. ${ }^{31}$ The precise contribution for each party has not been agreed in advance, but will be determined unilaterally by each party in accordance with its capabilities. Developed States will still take the lead, ${ }^{32}$ but developing States-notably China, the world's biggest GHG emitter, and India, the world's third biggest-are no longer exempt from making any emissions reductions, as they were under Kyoto. The understanding is that reductions are to increase progressively, insofar as each country's circumstances allow, "on the basis of equity, and in the context of sustainable development and efforts to eradicate poverty" ${ }^{33}$ Paris does at least reflect reality: it recognises that climate change is not caused only by developed states and that it cannot meaningfully be addressed by simplistic ideas of historic responsibility. China and India have to play their part. This development is an important milestone in the evolution of the UNFCCC regime.

Will the Paris Agreement be more successful than Kyoto at reducing GHG emissions? On the positive side the UN climate regime for the first time has a clear and verifiable objective defined by reference to global temperatures. Equally importantly all the principal GHG emitters share a common commitment to reduce GHG emissions, even if their individual contributions will still vary and be nationally determined. On the negative side, based on commitments made so far, global temperatures will continue to rise well beyond $2^{\circ}$ unless states progressively and significantly keep reducing their emissions. ${ }^{34}$ The Agreement could work, or it could fail by a large margin, but those who want to influence the outcome can still do so. That includes the human rights community.

\footnotetext{
${ }^{29}$ Articles 6, 7, 9.

${ }^{30}$ Preamble, 3rd recital. See generally Rajamani (2006), especially Ch 6, and id, (2016).

${ }^{31}$ Article 4.

${ }^{32}$ Article 4(4).

${ }^{33}$ Articles 3 and 4(3).

${ }^{34} \mathrm{UNEP}$, The Emissions Gap Report: Are the Copenhagen Accord pledges sufficient to limit global warming to $2^{\circ} \mathrm{C}$ or $1.5^{\circ} \mathrm{C}$ ? A preliminary assessment (Nairobi, 2010).
} 


\section{Human Rights and the Environment}

Why should environmental protection be treated as a human rights issue? There are several possible answers. ${ }^{35}$ Most obviously, and in contrast to the rest of international environmental law, a human rights perspective directly addresses environmental impacts on the life, health, private life, and property of individual humans rather than on other states or the global environment. It may serve to secure higher standards of environmental quality, based on the obligation of states to take measures to control pollution affecting health and private life. It helps to promote the rule of law in this context: governments become directly accountable for their failure to regulate and control environmental nuisances, including those caused by corporations, and for facilitating access to justice and enforcing environmental laws and judicial decisions. Lastly, the broadening of economic and social rights to embrace elements of the public interest in environmental protection has given new life to the idea that there is, or should be, in some form, a right to a healthy or decent environment. $^{36}$

Human rights jurisprudence relating to the environment has developed significantly in the past 25 years since the Rio Conference, but none of this owes anything to UN human rights bodies. An early attempt to adopt a UN declaration on human rights and the environment terminated in 1994 when an ambitious but politically controversial draft failed to secure the backing of states. ${ }^{37}$ The Office of the High Commissioner for Human Rights (OHCHR) returned to the problem in 2009, emphasizing that "While the universal human rights treaties do not refer to a specific right to a safe and healthy environment, the United Nations human rights treaty bodies all recognize the intrinsic link between the environment and the realization of a range of human rights, such as the right to life, to health, to food, to water, and to housing." 38 Three theoretical approaches were subsequently identified. ${ }^{39}$ The first sees the environment as a "precondition to the enjoyment of human rights". The second views human rights as "tools to address environmental issues, both procedurally and substantively". The third integrates human rights and the environment under the concept of sustainable development. Finally, the report also identifies "the

\footnotetext{
${ }^{35}$ See Boyle and Anderson (1996), Merrills (2007), Anton and Shelton (2011) and Boer (2015).

${ }^{36}$ See UNHRC, Preliminary Report of Independent Expert on human rights obligations relating to a safe, clean, healthy and sustainable environment, A/HRC/22/43 (2012) [“UNHRC Preliminary Rept (2012)"']; Knox and Pejan (2017).

${ }^{37}$ ECOSOC, Draft Declaration of Principles on Human Rights and the Environment, in Human Rights and the Environment, Final Report (1994) UN Doc E/CN 4/Sub 2/1994/9. See Popovic (1996).

${ }^{38}$ OHCHR, Report on Climate Change and Human Rights, UN Doc A/HRC/10/61 (2009) para 18 [“OHCHR 2009 Rept"]. On the difficult political background see Limon (2017), Ch 11.

${ }^{39} \mathrm{OHCHR}$, Analytical Study on the Relationship between Human Rights and the Environment, UN Doc A/HRC/19/34 (2011), paras. 2, 6-9 [“OHCHR 2011 Rept”].
} 
call from some quarters for the recognition of a human right to a healthy environment" and notes the alternative view that such a right in effect already exists. ${ }^{40}$

An independent expert-special rapporteur (Professor John Knox) was appointed by the UN Human Rights Commission (UNHRC) in 2012 to report on the substantive and procedural dimensions of human rights obligations relating to the enjoyment of a "safe, clean, healthy and sustainable environment" and the role of various institutional mechanisms in implementing those obligations. ${ }^{41}$ His reports articulate a largely uncontroversial account of what human rights law has contributed to environmental protection at the national and international level. The Special Rapporteur noted that "no global agreement sets out an explicit right to a healthy (or satisfactory, safe or sustainable) environment. . .Nor have the later conferences on sustainable development in Johannesburg in 2002 and Rio de Janeiro in 2012 proclaimed a right to a healthy environment." 42 However, his final report in 2018 advocates recognition of a right to a "safe, clean, healthy and sustainable environment", derived largely from existing human rights law. ${ }^{43}$

At the same time there is value in setting down those elements of human rights law already reflected in the jurisprudence and in national law, and on which some degree of international consensus is achievable. The rapporteur has at least demonstrated that regional environmental practice in Europe, Latin America and Africa has global significance, including the procedural rights enshrined in the Arhus Convention, the obligation to assess environmental impacts and ensure a reasonable balance between economic development and environmental protection, the need to implement and enforce applicable environmental standards, and to protect vulnerable groups such as indigenous peoples. ${ }^{44}$ But while the UNHRC now recognises the environmental dimensions of human rights law, ${ }^{45}$ including its relevance for sustainable development, it remains to be seen whether UN treaty bodies follow suit in a meaningful way. ${ }^{46}$

Does existing human rights law have any role in the process of tackling global climate change elaborated by the Paris Agreement? The OHCHR believes that it does. Its current policy asserts that "it is critical to apply a human rights-based approach to guide global policies and measures designed to address climate

\footnotetext{
${ }^{40} \mathrm{Ibid}$, para. 12.

${ }^{41}$ UNHRC Preliminary Rept (2012); Mapping Report, UN Doc A/HRC/25/53 (2013) [“UNHRC Mapping Rept (2013)"']; Compilation of Good Practices, UN Doc A/HRC/28/61 (2015); Note by Secretariat, UN Doc A/HRC/31/53 (2015). See generally Knox and Pejan (2017), Ch 1.

${ }^{42}$ UNHRC Preliminary Rept (2012), para. 14.

${ }^{43} \mathrm{UNHRC}$, Report of the Special Rapporteur on the issue of human rights obligations relating to the enjoyment of a safe, clean, healthy and sustainable environment, UN Doc A/HRC/37/59 (2018).

${ }^{44}$ See UNHRC Mapping Report (2013).

${ }^{45}$ UNHRC Resolution 31/8 (2016).

${ }^{46}$ The current practice of the Committee on the Rights of the Child, the Committee on the Elimination of Discrimination against Women, and the Committee on Economic Social and Cultural Rights with respect to climate change is reviewed in CIEL, States' Human Rights Obligations in the Context of Climate Change (Washington, 2018).
} 
change." 47 Its website identifies three "essential attributes" of a human rights approach:

- As policies and programmes are formulated, the main objective should be to fulfil human rights.

- The rights-holders and their entitlements must be identified as well as the corresponding duty-bearers and their obligations in order to find ways to strengthen the capacities of rights-holders to make their claims and of dutybearers to meet their obligations.

- Principles and standards derived from international human rights law_especially the Universal Declaration of Human Rights and the core universal human rights treaties, should guide all policies and programming in all phases of the process. ${ }^{48}$

In its submission to the Paris Conference in 2015 the OHCHR set out ten considerations that should guide states in the actions they take to address climate change ${ }^{49}$ Inter alia these include mitigating climate change and preventing negative effects on human rights; ensuring accountability and effective remedy for human rights harms caused by climate change; and guaranteeing equality, non-discrimination, and meaningful and informed participation in decision-making. States should co-operate to ensure an equitable outcome that delivers "low-carbon, climate-resilient, and sustainable development, while also rapidly reducing greenhouse gas emissions." The policy asserts that "Only by integrating human rights in climate actions and policies and empowering people to participate in policy formulation can States promote sustainability and ensure the accountability of all dutybearers for their actions. This, in turn, will promote consistency, policy coherence and the enjoyment of all human rights." 50

The UN human rights community is a late arrival at the climate change ball-very late. But if climate change is the problem, is human rights the answer, or even part of the answer? And is the OHCHR's vision of that answer plausible or realisable? For several reasons, it is far from clear that it is.

First, the whole tenor of the OHCHR's submissions to the Paris negotiations is anthropocentric insofar as it focused only on the harmful impact of climate change on the rights of humans, rather than on the environment as such. This is precisely the approach which ecological theorists have opposed because they believe it is insufficiently comprehensive and inconsistent with ecological reality and biological diversity. ${ }^{51}$ By looking at the problem in moral isolation from other species and

\footnotetext{
${ }^{47}$ See OHCHR website entry, "Human Rights and Climate Change: Overview", consulted 28/5/17, at http://www.ohchr.org/EN/Issues/HRAndClimateChange/Pages/HRClimateChangeIndex.aspx.

${ }^{48}$ Summarising the OHCHR website entry, previous fn.

${ }^{49}$ See "Understanding Human Rights and Climate Change", OHCHR's submission to the 21st Conference of Parties to the UNFCCC (27 November 2015) and the "Key Messages" reproduced on its website.

50"Key Messages", ibid.

${ }^{51}$ See Eckersley (1992) and Gillespie (1997).
} 
the natural world we simply reinforce the assumption that the environment and its natural resources exist only for immediate human benefit and have no intrinsic worth in themselves. But as we saw earlier, we cannot afford to ignore the fundamental value of natural capital - the climate, biodiversity, ecosystems, the marine environment and so on-in sustaining life on Earth. The Paris Agreement recognises this point. ${ }^{52}$ It is tempting to describe OHCHR's vision of human rights in this context as conceptually imperialist. A kinder view might be that it is simply myopic, for there is no inherent reason why a human rights perspective should not take a longer termperspective that balances competing values. Indeed, human rights law already recognises that environmental protection is a legitimate aim of public policy and law that may in some cases constrain or limit the exercise of the right to possessions and property or other human rights. ${ }^{53}$

Second, beyond a dogmatic reiteration of the importance of human rights, no real attempt is made by the OHCHR to explore or explain in any detail how its emphasis on fulfilling human rights as "the main objective" is supposed to save the climate from excessive warming in decades to come. The submissions do not go into detail and, not surprisingly, those who drafted the Paris Agreement evidently did not share the OHCHR's conception of its own centrality to the problem. Thus, right from the start we have a relationship that is poorly thought out, and on which only a limited consensus exists. $^{54}$

\section{Human Rights in the Paris Agreement}

The preamble to the Paris Agreement acknowledges that climate change is a common concern of humankind, and that "Parties should, when taking action to address climate change, respect, promote and consider their respective obligations on human rights, the right to health, the rights of indigenous peoples, local communities, migrants, children, persons with disabilities and people in vulnerable situations and the right to development, as well as gender equality, empowerment of women and intergenerational equity".

\footnotetext{
${ }^{52}$ Preamble, para. 13 , refers to "the importance of ensuring the integrity of all ecosystems, including oceans, and the protection on biodiversity...."

${ }^{53}$ Matos e Silva Lda v Portugal (1996) IV European Court of Human Rights ["ECHR"]; Jacobsson $v$ Sweden No 2 (1998) I ECHR; Katte Klitsche and de la Grange v Italy (1994) ECHR Sers A/293B; Pine Valley Developments Ltd v Ireland (1991) ECHR Sers A/222, paras. 57-9; Katsoulis and Ors v Greece [2004] ECHR 321; Fredin v Sweden (1991) ECHR Sers A/192, paras. 41-51. See also Apirana Mahuika and Ors v New Zealand (2000) CCPR Comm No 547/1992, in which the UN Human Rights Committee ["UNHR Ctte"] upheld the state's right to conserve and manage natural resources in the interests of future generations provided this did not amount to a denial of the applicant's rights.

${ }^{54}$ See Limon (2017), Ch 11.
} 
Despite much effort to achieve more during the negotiations, this is all the agreement says on the subject of human rights. ${ }^{55}$ It is even less specific or prescriptive than the OHCHR submissions. As Rajamani observes, "This recital carefully circumscribes the impact of an explicit reference to human rights in the Paris Agreement." ${ }^{, 56}$ Human rights law is neither incorporated into the Paris Agreement by this wording, nor does it explicitly constitute a standard by which the adequacy of efforts taken by the parties to implement the objectives of the Paris Agreement might be judged. ${ }^{57}$ Firstly, this paragraph is in the preamble, not the body of the treaty. It thus helps only to identify the object and purpose of the treaty and its context, not to impose obligations on the parties. 58 Second, it uses the word "should", not "shall", which implies a less than wholehearted endorsement of the relevance of the various rights referred to. ${ }^{59}$ The phrase "respect, promote and consider" further minimises any sense that the Agreement is reiterating a commitment to "fulfil" or "protect" human rights, the terms normally associated with human rights commitments. ${ }^{60}$ This choice of words was deliberate. At best it is little more than a recognition that, as the preamble says, states should take into account their human rights obligations when taking action to address climate change. To suggest that it brings about a "true incorporation of human rights into the Paris Agreement" is very wide of the mark. ${ }^{61}$ It does nothing of the kind. This preamble is not a triumph for the human rights lawyers.

Then there is the list of rights referred to in the preamble. It is a curious catalogue. The right to health is obviously relevant to climate change. But there is no mention of the right to private life, or life, or property, nor any of the social and economic rights that are also relevant, except the right to development. The word "sustainable" is notably absent here, although referred to elsewhere. Indigenous peoples, children, women, persons with disabilities all have rights, and all will be vulnerable to climate change, but why their rights should be singled out for special mention is not obvious. Overall this looks more like a list of categories designed to satisfy special interest groups rather than a serious attempt to address the relationship between human rights law and climate change. ${ }^{62}$ It is easy therefore to start from a sceptical position about Paris and human rights. Essentially the agreement says nothing meaningful on the subject. Does this matter? Yes it does.

\footnotetext{
${ }^{55}$ See Klein et al. (2017), pp. 108, 114-117; Rajamani (2010); Duyck (2015).

${ }^{56}$ Rajamani (2017).

${ }^{57}$ See Rajamani (2017). Contrast 1988 UN Convention Against Illicit Traffic in Narcotic Drugs, Article 14(2), which provides in part: "Each Party shall take appropriate measures to prevent illicit cultivation ... The measures adopted shall respect fundamental human rights..."

${ }^{58}$ Gardiner (2008).

${ }^{59}$ On the difference between "should" and "shall" see Nordquist (1993), II, pp. xlv-xlvi.

${ }^{60}$ Rajamani (2017); Klein et al. (2017), p. 115. Contrast UNHRC Resolution 31/8 (2016), which calls on states to "respect, protect, and fulfil human rights obligations".

${ }^{61}$ See Klein et al. (2017), p. 115.

${ }^{62}$ A point confirmed by Klein et al. (2017), p. 116.
} 
Climate change is already regarded in international law as a "common concern of humanity". 63 Thus it is an issue in respect of which all states have legitimate concerns. The UN is therefore right in principle to make the connection between human rights and climate change. ${ }^{64}$ The OHCHR's first report on the subject noted, however, that " $[\mathrm{w}]$ hile climate change has obvious implications for the enjoyment of human rights, it is less obvious whether, and to what extent, such effects can be qualified as human rights violations in a strict legal sense". ${ }^{65}$ That report goes on to observe the multiplicity of causes for environmental degradation and the difficulty of relating specific effects to historic emissions in any one state. But this is only partly true.

Governments obviously have a responsibility to protect their own citizens from the harmful effects of climate change, and this is where the rights of the most vulnerable groups are most relevant. The rights to life, health, water and food, and the right to respect for private life and property, entail more than a simple prohibition on government interference: governments have a positive duty to take appropriate action to secure these rights, ${ }^{66}$ as we can see in the human rights case law on environmental harm, where the problems were mainly a failure to regulate the activities of corporations, or to legislate on environmental matters, or to enforce existing environmental law. ${ }^{67}$ At this level it is worth emphasising that human rights obligations towards those most affected by climate change will at the very least require governments to take appropriate steps to mitigate the risk of harm within their own borders. If this is what the OHCHR had in mind then it is on safe ground, but it will have achieved very little.

However, in the climate change context, where the impacts are global, the key question is not whether GHG emitting states have to mitigate the harm to their own citizens, but whether they also have a responsibility to protect people in other states from the harmful impacts of those emissions on the global climate. The inhabitants of sinking islands in the South Seas may justifiably complain of human rights violations, but who is responsible? Those states like the United Kingdom and Germany whose historic emissions have unforeseeably caused the problem? Or those states like China and India whose current emissions are foreseeably making matters worse? Or those states like the United States or Canada which opted out of Kyoto and failed to take adequate measures to limit further emissions so as to stabilise global temperatures at 1990 levels? Or their own governments in the

\footnotetext{
${ }^{63} 1992$ UNFCCC, Preamble, 1st recital.

${ }^{64}$ UNHRC Resolution 10/4 (2009); id, Rept of the Independent Expert/Special Rapporteur etc, UN Doc A/HRC/31/52 (2016). See generally Humphreys (2009), Knox (2009), Boyle (2012) and Atapattu (2015).

${ }^{65}$ OHCHR 2009 Rept, para. 70.

${ }^{66}$ See UNHR Ctte, General Comment No 6 on Article 6 of the 1966 International Covenant on Civil and Political Rights, 16th Session, 1982.

${ }^{67}$ See e.g. Lopez Ostra v. Spain (1994) 20 EHRR 277; Guerra v. Italy (1998) 26 EHRR 357; Fadeyeva v. Russia [2005] ECHR 376; Öneryildiz v. Turkey [2004] ECHR 657; Taskin v. Turkey [2004] ECHR, paras. 113-9.
} 
Association of Small Island States, which may have conceded far too much when ratifying the Kyoto Protocol or in subsequent climate negotiations? In OHCHR's report the short answer is all of the above, and more. ${ }^{68}$

The legal problem with this answer is that human rights treaties generally require a state party to secure the relevant rights and freedoms for everyone within its own territory or subject to its jurisdiction. ${ }^{69}$ The extraterritorial application of human rights law has normally arisen only where the State exercises jurisdiction or control over persons or territory abroad. ${ }^{70}$ These precedents bear little resemblance to transboundary pollution, where the State only exercises jurisdiction over harmful activities located within its own territory, not over those who are harmed beyond its borders. They are even further removed from climate change. ${ }^{71}$ It is much harder to frame such a problem in terms of the jurisdiction or control over persons or territory required by the human rights case law. That is why the OHCHR's focus on "rightsholders" and "duty bearers" is misplaced and essentially incoherent in the context of climate change. It fails to capture adequately a global perspective on the problem.

But even if we accept that human rights law has transboundary application, it will still be hard to show that parties to the UNFCCC regime, including the major GHG emitters, have failed to strike the right balance between their own state's economic development and respect for human rights in other states ${ }^{72}$ when they have either complied with or are exempt from GHG emissions reduction targets established by

\footnotetext{
${ }^{68}$ See OHCHR 2009 Rept, paras. 86 and 99, and Limon (2017).

${ }^{69} 1966$ ICCPR, Article 2, but see Legal Consequences of the Construction of a Wall in the Occupied Palestinian Territory, Advisory Opinion, ICJ Reports (2004), 136, para. 109, and contrast the 1966 ICESCR which has no such limitation. The 1969 American Convention on Human Rights, Article 1 and the 1950 European Convention on Human Rights, Article 1, make no reference to territory, but require parties to ensure to everyone "subject to" or "within" their jurisdiction the rights set out therein. See generally De Schutter (2010), pp. 142-179.

${ }^{70}$ Legal Consequences of the Construction of a Wall in the Occupied Palestinian Territory, Advisory Opinion, ICJ Reports (2004), 136, paras. 109, 112; Application of the International Convention on the Elimination of All Forms of Racial Discrimination (Georgia v. Russian Federation), Provisional Measures Order, ICJ Reports (2008), 386, para. 109; Ecuador v. Colombia (Admissibility) [2010] Inter American Commission on Human Rights (IACHR) Report No. 112/10, paras. 89-100; Alejandre, Costa, de la Pena y Morales v. Republica de Cuba [1999] IACHR Report No. 86/99, para.23; Coard v. United States [1999] IACHR Report 109/99, para. 37; Al-Skeini v. United Kingdom [2011] ECtHR, paras. 130-42; Öcalan v. Turkey [2005] 41 European Human Rights Reports (EHRR) 985, para. 91; Ilascu v. Moldova and Russia [2005] 40 EHRR 46, paras. 310-19, 376-94; Issa et al. v Turkey [2004] 41 EHRR 567, para. 71; Cyprus v. Turkey [2002] 35 EHRR 30, para. 78. See also General Comment No. 31 adopted by the UNHR Ctte, UN Doc. HRI/GEN/1/Rev.7, 192 at 194ff, para. 10.

${ }^{71}$ See the arguments in Boyle (2012), p. 613. In 2016 a German court dismissed a case brought by a Peruvian farmer against a German energy company on the basis that RWE had no duty to protect Peruvians from flooding caused by climate change. The case is currently on appeal: see https:// business-humanrights.org/en/rwe-lawsuit-re-climate-change. The Philippines Commission on Human Rights is currently investigating whether foreign fossil fuel companies have violated the human rights of Filippinos who have endured climate-related disasters.

${ }^{72}$ Taskin v Turkey, ECHR (2004), para. 119; Hatton v. UK, ECHR (2003) 28, paras. 98, 122-9 (Grand Chamber).
} 
Kyoto and agreed by the international community as a whole. ${ }^{73}$ Inadequately controlled transboundary pollution is clearly a breach of general international law, ${ }^{74}$ and may in limited circumstances also engage those human rights which potentially entail cross-border jurisdiction. ${ }^{75}$ But, given the terms of the Kyoto Protocol, and the essentially voluntary character of key provisions of the Paris Agreement, ${ }^{76}$ it is far from clear that inadequately controlled climate change violates any existing treaty obligations or general international law. In those circumstances the argument that it nevertheless violates the existing human rights obligations of states is not easy to make.

\section{Is There Another View?}

The UN independent expert/special rapporteur appointed to report on climate change and human rights, Professor John Knox, has observed that "whether or not climate change legally violates human rights norms is not the dispositive question." $" 77 \mathrm{He}$ takes a more insightful approach than the one adopted by OHCHR. His report emphasises the global character of the threat climate change poses for the enjoyment of human rights and focuses on the need for global cooperation to tackle climate change effectively in order to avert serious harm to those rights. He argues that obligations to protect human rights in the context of internal environmental harm "can also inform the content of the duty of international cooperation when that duty pertains to a global environmental challenge such as climate change." $" 78$ On this view of human rights law "All states have a duty to work together to address climate change, but the particular responsibilities necessary and appropriate for each State will depend in part upon its situation.",79

Building on the 2015 Paris Agreement, Professor Knox reiterates the obligation of states to assess the climatic effects of activities within their jurisdiction; to control the activities of business and industry when these may cause climate change; to facilitate public participation in decision-making with respect to climate change; and

\footnotetext{
${ }^{73}$ Greenhouse gas emissions reduction targets under Kyoto apply only to Annex I developed state parties, not to developing countries, including China, India and Brazil.

${ }^{74}$ Pulp Mills on the River Uruguay Case, ICJ Reports (2010), paras. 101, 187.

${ }^{75}$ E.g. the right of equal access to justice, on which see 1998 Arhus Convention on Access to Information, Public Participation in Environmental Decision-making and Access to Justice, Article 3(9).

${ }^{76}$ On the question how far the specific provisions of the Paris Agreement create legally binding obligations see Bodansky (2016b). In particular he notes, ibid, at 150, that "The Paris Agreement does not require parties to implement their NDCs; instead it simply requires parties to pursue domestic mitigation measures, an obligation they already have under the UNFCCC."

${ }^{77} \mathrm{UN}$ Doc A/HRC/31/52 (2016), para. 36.

${ }^{78}$ Ibid, para. 45 .

${ }^{79}$ Ibid, para. 46.
} 
to provide effective remedies for those adversely affected. All of this reflects existing human rights-based environmental jurisprudence. ${ }^{80}$ His most important conclusion is that by itself the Paris Agreement will not prevent "disastrous consequences for human rights if states merely meet the commitments they have undertaken so far." It follows that "[f]rom a human rights perspective, then, it is necessary not only to implement the current intended contributions, but also to strengthen those contributions to meet the target set out in article 2 of the Paris Agreement." ${ }^{, 81}$

Knox's human rights perspective is considerably more focused and persuasive than the submissions made by the OHCHR to the Paris negotiations. Its utility is partly rhetorical, but if used effectively by UN human rights bodies to focus attention on how states parties respond (or fail to respond) to commitments made in the Paris Agreement it has potential juridical significance, comparable to the economic and social rights from which it draws inspiration. This represents a significant contribution to the debate on human rights and climate change. It may suggest that economic and social rights provide the best framework for that debate at the global level. Economic and social rights are generally concerned with encouraging governments to pursue policies which create conditions of life enabling individuals or peoples to develop to their full potential. They are programmatic, entailing progressive realization in accordance with available resources, but nevertheless requiring states to "ensure the satisfaction of, at the very least, minimum essential levels of each of the rights". 82

The debate on climate change and human rights thus broadens out into a focus on environmental quality and sustainability. But despite the efforts of the UN human rights treaty organs to invest the 1966 International Covenant on Economic, Social and Cultural Rights ("ICESCR") with greater environmental relevance, it still falls short of giving environmental quality and sustainability, including the quality and sustainability of the global environment, recognition as a significant public interest. ${ }^{83}$ Crucially, there is no right to a safe, clean, healthy or sustainable environment in the Covenant. ${ }^{84}$ Lacking the status of a right means that the environment can be trumped by those values that have that status, including the right to economic

\footnotetext{
${ }^{80}$ Supra, n. 67.

${ }^{81}$ UN Doc A/HRC/31/52 (2016), paras. 72-84. See also Knox (2016).

${ }^{82}$ UN Committee on Economic Social and Cultural Rights ["UNCESCR"], General Comment No 3: The Nature of States' Parties Obligations (1990) (interpreting Article 2 of the Covenant). See Craven (1995), Ch 3.

${ }^{83}$ The UNCESCR has adopted various General Comments relevant to the environment and sustainable development, notably General Comments 14 and 15, which interpret Articles 11 and 12 of the ICESCR to include access to sufficient, safe, and affordable water for domestic uses and sanitation. See UNCESCR, General Comment No. 14: The Right to the Highest Attainable Standard of Health, UN Doc E/C.12/2000/4, 11 August 2000; General Comment No. 15: The Right to Water, UN Doc E/C.12/2002/11, 20 January 2003.

${ }^{84}$ Though there is a right to health and environmental hygiene (Article 12). Compare UNHRC Resolution 31/8 (2016), para. 5(a), which encourages States "To adopt an effective normative framework for the enjoyment of a safe, clean, healthy and sustainable environment."
} 
development and natural resource exploitation. ${ }^{85}$ This is an omission that needs to be addressed if the sustainability of the global environment as a public good is to receive the weight it deserves in the balance of economic, social and cultural rights.

The key question therefore is what values we think a covenant on economic and social rights should recognize in the modern world. Is protection of the global environment, including the global climate system, a sufficiently important public good to merit economic and social rights status comparable to economic development? The answer to this question surely has to be yes. The UN has repeatedly endorsed the promotion of sustainable development as the core principle of international environmental law and policy for all states. ${ }^{86}$ This is reflected in the Paris Agreement's references to sustainable development. ${ }^{87}$ Is it now time to ensure that it is also reflected in human rights law ${ }^{88}$

The challenge posed by sustainable development is to ensure that environmental protection is fully integrated into economic policy. Acknowledging that the environment is part of this equation, both the 1992 Rio Declaration (Principle 3) and the 1993 Vienna Declaration on Human Rights (paragraph 11) emphasize that " $[\mathrm{t}] \mathrm{he}$ right to development should be fulfilled so as to meet equitably the developmental and environmental needs of present and future generations". For political reasonsbecause the issue remains controversial-this is a perspective wholly absent from the OHCHR's vision of the role of human rights law in the Paris negotiations. ${ }^{89}$ Yet, as a matter of law, the International Court of Justice (ICJ) has repeatedly referred to "the need to reconcile economic development with protection of the environment [which] is aptly expressed in the concept of sustainable development". 90 The essential point is that, while recognising that the right to pursue economic development is an attribute of a State's sovereignty over its own natural resources and territory, it cannot lawfully be exercised without regard for the detrimental impact on the sustainability of the global environment or on human rights in general. The Paris Agreement is important precisely because it provides a clearer yardstick by which to measure that detrimental impact than previous climate change agreements have done.

\footnotetext{
${ }^{85}$ Pursuant to Article 1 of both 1966 Covenants. See Merrills (2007), p. 666.

${ }^{86}$ Report of the World Summit on Sustainable Development, UN Doc. A/CONF.199/20, 26 August4 September 2002, Resolution 1, para. 5.

${ }^{87}$ See Preamble and Articles 2, 4, 5, 6, 7, and 8.

${ }^{88}$ See generally Knox and Pejan (2017).

${ }^{89}$ See Limon (2017) and Rajamani (2017).

${ }^{90}$ Pulp Mills on the River Uruguay Case, ICJ Reports (2010) 14, para. 177; Gabčíkovo-Nagymaros Project (Hungary/Slovakia), ICJ Reports (1997) 7, para. 140; Iron Rhine Case, PCA (2005); Higgins (1999).
} 


\section{Conclusions}

The Paris Agreement is so far the first, but hopefully not the last, attempt to promote the 'urgent action' to deal with climate change envisaged by SDG 13. This conclusion is obvious and uncontroversial. Beyond that, it is harder to draw clear conclusions about how far Paris has embraced a human rights approach to climate change. The Paris Agreement is relevant to human rights law, but not for what it says about human rights - which is next to nothing - but for what it says about the need to address the risk of climate change taking global temperatures above $1.5^{\circ} \mathrm{C}$. In order to help ensure that states parties meet this goal, and avoid the serious harm to sustainable development and the enjoyment of human rights that will otherwise result, the UN special rapporteur is right in principle to argue that human rights law as a whole requires states to comply with expectations set out in Articles 2, 3 and 4 of the Agreement. UN human rights bodies need to act accordingly and hold states to account for what they have agreed in Paris. Climate change is a global problem. It cannot easily be addressed by the simple process of giving specific human rights transboundary effect. It affects too many states and too much of humanity. Its causes, its effects, and those responsible, are too numerous and too widely spread to respond usefully to individual human rights claims or to analysis by reference to particular human rights.

The response of human rights law-if it is to have one-needs to be in global terms, treating the global environment and climate as the common concern of humanity, and climate change as a threat to human rights as a whole, but in particular to economic and social rights. In that context focusing on climate change within the corpus and institutional structures of economic, social and cultural rights makes sense, even if it means giving a broader interpretation to those rights or amending the 1966 ICESCR. The policies of individual states on energy use, reduction of greenhouse gas emissions, land use and deforestation could then be scrutinised and balanced against the evidence of their global impact on human rights and sustainable development. This is not a panacea for failure to make progress in implementing the Paris Agreement, but it would give the rights of humanity as a whole a voice that at present is scarcely heard. Whether the UN Human Rights Commission or the Office of the High Commissioner for Human Rights wish to travel down this road is another question, for politicians in Geneva to answer rather than international lawyers, but that is where they must go if they wish to say anything meaningful about climate change and human rights.

\section{References}

\section{Books}

Anton D, Shelton D (2011) Environmental protection and human rights. CUP, Cambridge Atapattu S (2015) Human rights approaches to climate change: challenges and opportunities. Routledge, Abingdon 
Boer B (ed) (2015) Environmental law dimensions of human rights. OUP, Oxford

Boyle A, Anderson M (eds) (1996) Human rights approaches to environmental protection. OUP, Oxford

Craven M (1995) The international covenant on economic, social and cultural rights. OUP, Oxford

De Schutter O (2010) International human rights law: cases, materials, commentary. CUP, Cambridge

Dresner S (2008) The principles of sustainability, 2nd edn. Routledge, London

Eckersley R (1992) Environmentalism and political theory. UCL Press, London

Gardiner R (2008) Treaty interpretation. OUP, Oxford

Gillespie A (1997) International environmental law, policy and ethics. OUP, Oxford

Goldin I, Winters L (eds) (1995) The economics of sustainable development. CUP, Cambridge

Helm D (2016) Natural capital: valuing the planet. Yale UP, London

Humphreys S (ed) (2009) Human rights and climate change. OUP, Oxford

Intergovernmental Panel on Climate Change (2013) Climate Change 2013: The Physical Science Basis: Working Group I Contribution to the Fifth Assessment Report of the Intergovernmental Panel on Climate Change. CUP, Cambridge

Jacobs M (1991) The green economy. Pluto Press, London

Klein D, Carazo M, Doelle M, Bulmer J, Higham A (eds) (2017) The Paris Agreement on climate change. OUP, Oxford

Knox J, Pejan R (eds) (2017) The human right to a healthy environment. CUP, Cambridge

Moffatt I (1995) Sustainable development: principles, analysis and policies. CRC Press, London

Neumayer E (2013) Weak versus strong sustainability, 4th edn. E Elgar, London

Nordquist M (ed) (1993) United Nations Convention on the Law of the Sea 1982: a commentary. Nijhoff, Dordrecht

Rajamani L (2006) Differential treatment in international environmental law. OUP, Oxford Redclift M (1987) Sustainable development: exploring the contradictions. Methuen, London

Reid D (1995) Sustainable development. Earthscan, London

\section{Book Chapters}

Higgins R (1999) Natural resources in the case law of the international court. In: Boyle A, Freestone D (eds) International law and sustainable development. OUP, Oxford, p 87

Knox J (2016) Human rights principles and climate change. In: Carlarne C, Gray K, Tarasofsky R (eds) The Oxford handbook of international climate change law. OUP, Oxford, p 213

Limon M (2017) The politics of human rights, the environment, and climate change at the human rights council: towards a universal right to a healthy environment? In: Knox J, Pejan R (eds) The human right to a healthy environment. CUP, Cambridge, Ch 11

Merrills J (2007) Environmental rights. In: Bodansky, Brunnée, Hey (eds) The Oxford handbook of international environmental law. OUP, Oxford, p 663

Rajamani L (2017) Human rights in the climate change regime: from Rio to Paris and beyond. In: Knox, Pejan (eds) The human right to a healthy environment. CUP, Cambridge, Ch 13 


\title{
Journal Articles
}

Bodansky D (2016a) The Paris climate change agreement: a new hope? Am J Int Law 110:306 Bodansky D (2016b) The legal character of the Paris Agreement. Rev Eur Community Int Environ Law 25:142

Boyle A (2012) Human rights and the environment: where next? Eur J Int Law 23:613

Duyck S (2015) The Paris climate agreement and the protection of human rights in a changing climate. Yearb Int Environ Law 26:3

Knox J (2009) Linking human rights and climate change at the UN. Harv Environ Law Rev 33:477

Morgera E, Savaresi A (2012) A conceptual and legal perspective on the green economy. Rev Eur Community Int Environ Law 22:14

Popovic N (1996) In pursuit of human rights: commentary on the draft declaration of principles on human rights and the environment. Columbia Hum Rights Law Rev 27:487

Rajamani L (2010) The increasing currency and relevance of rights-based perspectives in the international negotiations on climate change. J Environ Law 22:391

Rajamani L (2016) Ambition and differentiation in the 2015 Paris Agreement: interpretative possibilities and underlying politics. Int Comp Law Q 65:493

\begin{abstract}
Alan Boyle is Emeritus Professor of Public International Law at the University of Edinburgh. He is a specialist in public international law, especially international environmental law, law of the sea, international law-making and international litigation. He has worked regularly as a consultant or as counsel for various governments, international organizations and NGOs on general international law, international environmental law and law of the sea. Inter alia he has appeared as counsel in six cases brought under the 1982 UN Convention on the Law of the Sea. He is one of the leading practitioners in that field and in international environmental litigation, where he has been counsel in many of the leading cases. Educated at Oxford University, he has also taught at the University of London (Queen Mary College); University of Texas Law School; William and Mary College Law School, Virginia; the University of Paris and LUISS in Rome. He is a barrister and practices occasionally in the International Court of Justice and other international tribunals, mainly in environmental and law of the sea cases.
\end{abstract}

Open Access This chapter is licensed under the terms of the Creative Commons Attribution 4.0 International License (http://creativecommons.org/licenses/by/4.0/), which permits use, sharing, adaptation, distribution and reproduction in any medium or format, as long as you give appropriate credit to the original author(s) and the source, provide a link to the Creative Commons licence and indicate if changes were made.

The images or other third party material in this chapter are included in the chapter's Creative Commons licence, unless indicated otherwise in a credit line to the material. If material is not included in the chapter's Creative Commons licence and your intended use is not permitted by statutory regulation or exceeds the permitted use, you will need to obtain permission directly from the copyright holder.

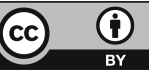

